\title{
ENERGETICS OF YELLOW-BELLIED MARMOT POPULATIONS ${ }^{1}$
}

\author{
Delbert L. Kilgore, Jr. ${ }^{2}$ and Kenneth B. Armitage \\ Division of Biological Sciences, The University of Kansas, Lawrence, Kansas 66045 USA
}

\begin{abstract}
The energy dynamics of 2 colonies of yellow-bellied marmots (Marmota flaviventris) were studied in the Rocky Mountains of central Colorado in 1969 and 1970. The Intake-Rejecta and Maintenance-Production models, which included an analysis of seasonal variations in energy flow parameters, yielded similar estimates of population energy flow.

Colony energy flow ranged from 64.0 to $94.6 \mathrm{~kJ} \cdot \mathrm{m}^{-2} \cdot \mathrm{yr}^{-1}$. Differences between colonies in annual energy flow can be explained by variations in biomass. Peak energy flow occurred at different times in the 2 colonies and the timing was related to reproductive conditions.

The marmot populations consumed 94.6 to $119.2 \mathrm{~kJ} \cdot \mathrm{m}^{-2} \cdot \mathrm{yr}^{-1}$, which represented 0.8 to $3.1 \%$ of the aboveground primary production. The efficiency with which the marmot populations exploited the available net primary production was 2 to $6.4 \%$. Seventy-one to $75 \%$ of the energy ingested by the populations was assimilated; only $77 \%$ of the assimilated energy went into maintenance of the population biomass. Tissue growth efficiency averaged $16.8 \%, \approx 5 \times$ greater than typical homeotherms. The production/maintenance ratio averaged $29.6 \%$.

The marked differences in the respiration efficiences, tissue growth efficiencies, and production:maintenance ratios between the heterothermic marmot and typical homeotherms suggest that heterothermy represents a distinct strategy in secondary production.
\end{abstract}

Key words: Assimilation; Colorado; energetics; growth; heterotherm; hibernation; Marmota flaviventris; marmots; production; reproduction.

\section{INTRODUCTION}

There are at least 2 distinct strategies in secondary production that are related to "modes" of thermoregulation. Mammals and birds use $\approx 98 \%$ of assimilated energy in maintenance, while invertebrates use $\approx 78 \%$ (Golley 1968). The tissue growth efficiency, the ratio of secondary production to assimilated energy (Kozlovsky 1968), of homeotherms is considerably less than that of poikilothermic invertebrates. However, further speculation on the significance of this functional distinction between poikilotherms and homeotherms has been curtailed by lack of information on population energetics of organisms not categorically homeotherms or poikilotherms (Golley 1968).

Quantitative information on energy flow in mammalian hibernators, particularly those that store fat versus food, is scarce despite the contributions of Wiegert and Evans (1967), Hansen and Reed (1969), and Haberman and Fleharty (1971). Therefore, the purpose of the present study was to analyze energy flow in natural populations of a classical hibernator, the yellow-bellied marmot (Marmota flaviventris). The specific question asked was: How does energy flow through populations of this hibernator differ from that through populations of nonhibernating mammals?

Information on the life history of yellow-bellied marmots appears elsewhere (Armitage 1962, 1965, 1974). Of particular importance to this study is that marmots are social and that they are active, not hibernating, less than half of each year. The term colony refers to social groups of marmots consisting of 1 or

\footnotetext{
${ }^{1}$ Manuscript received 24 January 1977; accepted 1 September 1977.

${ }^{2}$ Present address: Department of Zoology, University of Montana, Missoula, Montana 59812 USA.
}

more polygamous units and some nonreproductive individuals (yearlings and young) occupying a circumscribed habitat (Downhower and Armitage 1971, Svendsen 1974).

In 1969 and 1970, the energy flow through 2 marmot colonies in the vicinity of the Rocky Mountain Biological Laboratory, located at an elevation of 2,900 metres on the East River in the Elk Mountain Range, Gunnison County, Colorado, was studied. Marmots in this area are active in most years from May through September.

\section{METHODS \\ The study area}

Colonies 1 and 4 (Armitage 1974) occupied portions of an extensive but discontinuous grassland situated on the floor of the East River Valley. The species composition of this alluvial grassland is similar to the Festuca thurberi community type (Langenheim 1956, 1962), dominated by Bromus richardsonii, Bromus porteri, and Poa spp. (primarily secunda and alpina). Also abundant is Potentilla gracilis, Taraxacum officinale, Stipa lettermanii, Achillea millefolium, Mertensia viridis, Lathyrus leucanthus, Linum lewisii, Melica spectabilis, and Agoseris glauca. Artemisia tridentata appears throughout the area but is more prominent in the southern portion of the valley at lower elevations. Nomenclature used here is that of Barrell (1969).

\section{Approach and operational definitions}

Because there is no direct method for measuring energy flow in terrestrial vertebrate populations, energy flow, defined as assimilated energy $\left(E_{A}\right)$, must be estimated from other parameters that can be measured in 
the laboratory or field. The accuracy of estimates obtained in this fashion is questionable. However, the reliability of energy flow estimates can be enhanced by including in any predictive model the biotic and nonbiotic factors which affect energy flow parameters, such that a significant portion of the variation in these parameters is explained. Probably the most substantial error in estimating population energy flow results from inprecise determination of population biomass. This error is minimal in estimates of energy flow in marmots as the standing crop of the population can be accurately determined at any time during the active season.

With certain assumptions (Golley 1967) energy flow $\left(E_{F}\right)$ of a population may be estimated as either the difference between energy intake $\left(E_{1}\right)$ and that lost in excreta $\left(E_{\mathrm{FU}}\right)$ in a given time period (The IntakeRejecta Model) or as the sum of the energy expended in maintenance $\left(E_{R}\right)$ of the population biomass and the net productivity $\left(E_{P}\right)$ of the population (The Maintenance-Production Model) (Petrusewicz 1967).

$E_{F U}$ is the sum of the energy in feces and urine although energy in the urine could be considered a firstorder loss of assimilated energy. We used the following operational definitions (after Petrusewicz 1967): digested energy is the energy consumed minus the energy of feces; assimilation energy is digested energy minus the energy of urine.

Energy expended for maintenance $\left(E_{R}\right)$ is dependent on a complex of environmental and behavioral factors. However, we consider variations in activity of individuals and in the environmental temperatures to which individuals were exposed to be the primary factors affecting the magnitude of $E_{R}$.

The energy cost of activity is rarely determined in studies of energy flow. Instead, a total cost of maintenance is determined either through the measurement of a daily energy budget (DEB) (Grodzinski and Gorecki 1967) or by the addition of an activity component (constant) to the daily resting metabolism, with or without consideration for the duration or intensity of activity (McNab 1963). Metabolism is measured indirectly as $\mathrm{O}_{2}$ consumption. The methodology of determining a DEB is not appropriate for marmots; therefore, the second approach was taken. In addition to the duration of activity, adjustments for the level of activity were also included. Three levels of activity were recognized in marmots as these are quantifiable by direct observation. The energy expended at each of these levels is denoted $E_{m l}, E_{m 2}$, and $E_{m 3}$ for future reference and represent, respectively, energy expended during rest, moderate activity (e.g., foraging), and locomotion. Maintenance energy at the 3 levels of activity and at varying air temperatures can be computed as follows:

$$
\begin{gathered}
\mathrm{E}_{\mathrm{ml}}=\mathrm{M}_{\text {rest }} \mathrm{Wt}, \\
\text { since, } \\
\mathrm{M}_{\mathrm{rest}}\left(\mathrm{J} \cdot \mathrm{g}^{-1} \mathrm{~h}^{-1}\right)=a+b \mathrm{~T}_{\mathrm{a}} \\
\mathrm{E}_{\mathrm{ml}}=\left(a+b \mathrm{~T}_{\mathrm{a}}\right) \mathrm{Wt} ;
\end{gathered}
$$

$$
\begin{aligned}
& \mathrm{E}_{\mathrm{m} 2}=1.7 \mathrm{E}_{\mathrm{ml}} \\
& \mathrm{E}_{\mathrm{m} 3}=\mathrm{M}_{\mathrm{run}} \mathrm{kdn}
\end{aligned}
$$

and since,

$$
\begin{gathered}
\mathrm{M}_{\text {run }}\left(\mathrm{m} 1 \mathrm{O}_{2} \mathrm{~km}^{-1}\right)=8.46 \mathrm{~W}^{0.60}+\left(6.0 \mathrm{~W}^{0.75}\right) / \mathrm{V} \\
\mathrm{E}_{\mathrm{m} 3}=\left[8.46 \mathrm{~W}^{0.60}+\left(6.0 \mathrm{~W}^{0.75}\right) / \mathrm{V}\right] \mathrm{kdn},
\end{gathered}
$$

where $a$ and $b$ represent, respectively, the $Y$-intercept and slope for the relationship between metabolism and air temperature $\left(\mathrm{T}_{\mathrm{a}}\right), \mathrm{W}$ is the body weight $(\mathrm{g})$ of the animal, $t$ is the total time $(\mathrm{h})$ active at the particular level of activity, $\mathrm{V}$ is the velocity of locomotion (kilometres per hour), d represents the average distance run (kilometres), $\mathrm{k}$ is a constant for the energy equivalent of $\mathrm{O}_{2}\left(20.9 \mathrm{~J} /\right.$ millilitre $\mathrm{O}_{2}$ consumed $)$, and $\mathrm{n}$ is the number of times an animal ran distance $d$. The relationship between resting metabolism and air temperature, Eq. $1 a$, is linear over the range of 5 to $25^{\circ} \mathrm{C}$ in marmots (Fig. 1). The constant 1.7 in Eq. 2 is derived from the effect of "posture", on metabolism (Taylor et al. 1970). In Eq. $3 b$, it is assumed that during each locomotory period marmots traveled a fixed distance (d); therefore, this equation computes the energy cost of 1 locomotory period. The value of $\mathrm{k}$ in Eq. $3 b$ assumes a respiratory quotient (RQ) of 1 . Although the $R Q$ of running mammals is not known, the error in $E_{R}$ resulting from this assumption will be negligible. Equation $3 a$ relating the energy cost of locomotion to body weight is from Taylor et al. (1970).

Equations $1 a$ through $3 b$ are based on the following assumptions: (1) that heat production resulting from activity is not available for thermoregulation (Jansky 1962); (2) that the relationship between heat production of activity and air temperature is the same as that for the resting rate of metabolism; and (3) that the velocity of locomotion in marmots is such that the cost of running $\left(\mathrm{M}_{\text {run }}\right)$ has reached a minimum. For an individual marmot on a particular day,

$$
\mathrm{E}_{\mathrm{R}}=\sum_{\mathrm{i}=1}^{3} \mathrm{E}_{\mathrm{mi}} \text {. }
$$

Net productivity (Petrusewicz 1967:21) has 2 major components, that due to reproduction $\left(E_{r}\right)$ and that resulting from growth and fat deposition $\left(\mathrm{E}_{\mathrm{g}}\right)$. The following equations used to compute net secondary productivity of marmot populations are similar to the production equations of Petrusewicz and Macfadyen (1970); however, we modified the equations to include the net efficiency $\left(\mathrm{E}_{\mathrm{g}} / \mathrm{E}_{\mathrm{A}}\right)(e)$ of growth and fat deposition. The use of the net efficiency of growth in calculating the energy of growth separates maintenance costs $\left(E_{R}\right)$ from costs of converting assimilated energy into energy of tissues. Neither the energy value of marmot tissue nor the net efficiency of growth was determined; instead, values from other rodents were used: energy value of live-weight tissue of neonates $\left(\mathrm{K}_{1}\right), 4.31 \mathrm{~kJ} / \mathrm{g}$ (Gorecki 1965), of weanling animals $\left(\mathrm{K}_{2}\right), 6.0 \mathrm{~kJ} / \mathrm{g}$ 


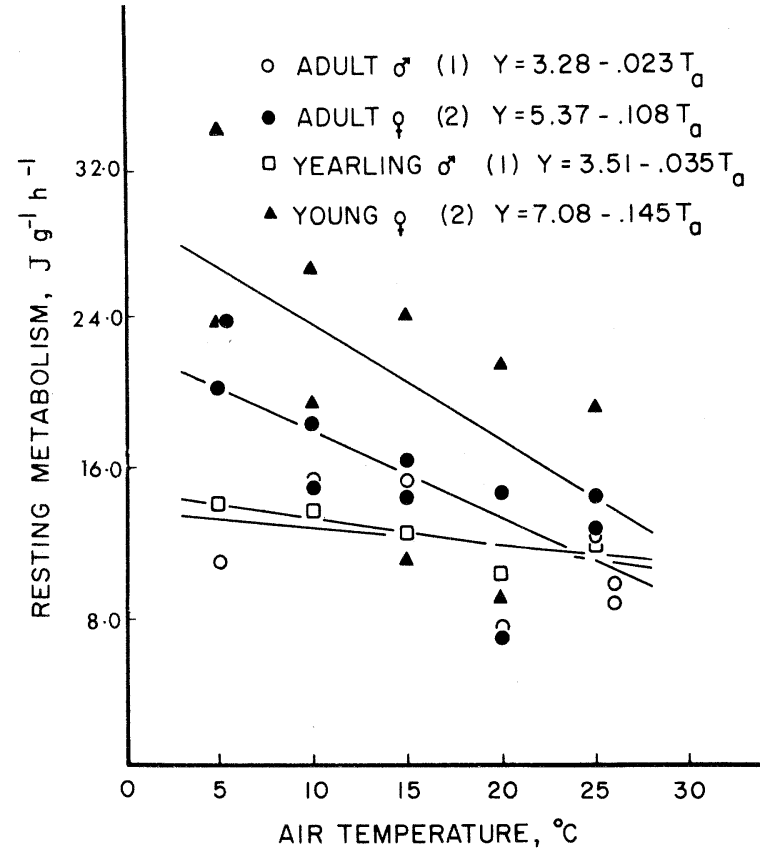

FIG. 1. Relationship between unadjusted metabolic rate of nonfasted marmots at rest and air temperature $\left(\mathrm{T}_{\mathrm{a}}\right)$. The lines were fitted by the least-squares method and are described by the equations included in the figure.

(Kaczmarski 1966), and of yearlings and adults $\left(\mathrm{K}_{3}\right)$, $6.3 \mathrm{~kJ} / \mathrm{g}$ (Gorecki 1965); net efficiency of growth of lean tissue $\left(e_{1}\right), 50 \%$ (Soholt 1973); net efficiency of fat deposition $\left(e_{2}\right), 30 \%$ was calculated from Kleiber (1961:292). We assumed that marmots $<3$ yr old deposited fat in the same proportions as woodchucks when body weight increased linearly (Snyder et al. 1961): adult males $31.4 \%\left(c_{1}\right)$, adult females $44.1 \%\left(c_{2}\right)$, yearling males $14.2 \%\left(\mathrm{c}_{3}\right)$, yearling females $16.8 \%\left(\mathrm{c}_{4}\right)$, young males $7.5 \%\left(\mathrm{c}_{5}\right)$, and young females $8.3 \%\left(\mathrm{c}_{6}\right)$. Since June or "lean" weights of adult male and female marmots $3 \mathrm{yr}$ of age and older are not significantly different $(P>.05)$, increases in their weight during the active season are $100 \%$ fat. The energy equivalent of fat is $38.1 \mathrm{~kJ} / \mathrm{g}\left(\mathrm{K}_{4}\right)$ (Kaufman and Kaufman 1975). The summary equation for secondary production of a population is:

$$
\begin{array}{cc} 
& E_{\mathrm{p}}=\mathrm{E}_{\mathrm{r}}+\mathrm{E}_{\mathrm{g}}, \\
\text { where, } & \mathrm{E}_{\mathrm{r}}=\frac{\left[(\mathrm{N} \overline{\mathrm{W}}) \mathrm{K}_{1}\right]}{e_{1}}
\end{array}
$$

and

$$
\begin{aligned}
\mathrm{E}_{\mathrm{g}}= & \frac{(\Delta \mathrm{W} / \Delta \mathrm{t}) \mathrm{tK}_{2}}{e_{1}}+\frac{1-\mathrm{c}_{\mathrm{i}}(\Delta \mathrm{W} / \Delta \mathrm{t}) \mathrm{tK}_{3}}{e_{1}} \\
& +\frac{\mathrm{c}_{\mathrm{i}}(\Delta \mathrm{W} / \Delta \mathrm{t}) \mathrm{tK}_{4}}{e_{2}},
\end{aligned}
$$

since, $\quad(\Delta \mathrm{W} / \Delta \mathrm{t})=b$,

$$
\mathrm{E}_{\mathrm{g}}=\frac{\left[(b) \mathrm{tK}_{2}\right]+\left[1-\mathrm{c}_{\mathrm{i}}(b) \mathrm{t} \mathrm{K}_{3}\right]}{e_{1}}+\frac{\mathrm{ci}(b) \mathrm{tK}}{e_{2}}
$$

where, $b$ or $(\Delta \mathrm{W} / \Delta \mathrm{t})$ is the rate (grams per day) at which an individual gained weight, $t$ is the number of days an individual is in a particular life stage, $\mathrm{N}$ is the total number of young born to the population, and $\bar{W}$ is the mean birth weight of young $(\mathrm{g})$. $\mathrm{E}_{\mathrm{g}}$ can be computed for each individual and summed for a population value. Growth and fat deposition in marmots is linearly related to time (Armitage et al. 1976).

Dispersal of individuals from the populations was considered a loss of biomass or "negative production." The energy equivalent of their biomass was deducted from all calculations of maintenance and production subsequent to their departure.

\section{Field studies}

The diurnal activity and large size of marmots permits precise determination of their number in a colony and of their foraging area. Forage sites of individual marmots were recorded on scaled maps of each colony's habitat. The total area used for foraging for each colony was determined by pooling individual forage sites, connecting these points in a manner as to minimize the enclosed area (i.e., by forming discrete isolated areas), and measuring the enclosed areas with a compensating polar planimeter.

An analysis of primary production and species composition of the grassland areas preceded the actual delineation of the colony feeding areas. Based on observational data collected in 1968 , broad areas surrounding burrow sites of each colony were tentatively defined as potential feeding areas; these areas were subsequently divided into square metre grids and sample plots were selected randomly. The number of sample plots selected in each area varied with the heterogeneity of the vegetation, but at both sites $\approx 0.5 \%$ of the total area was sampled. During the growing season the vegetation was frequently sampled by clipping all the plants within a 0.1 -metre ${ }^{2}$ subsample of each square metre plot. A given subsample was clipped only once. At the same time, aboveground portions of those species present in the sample plots were collected, dried to a constant weight, and their energy value determined as described below. Standing crop was calculated by extrapolation of the dry weight and energy data to the composition analysis of the sample plots. Net primary production was assumed to be the energy equivalent of the maximum standing crop. This estimate of net primary production is minimal as it does not include production consumed by marmots, insects, or other herbivores (e.g., Microtus montanus). This source of error probably is small because insect and small mammal populations were greatly depressed in 1969-1970 (Ehrlich et al. 1972). Also, inspection of the sample plots yielded no evidence of grazing by marmots within any of the $0.1-$ metre $^{2}$ subsamples.

Air temperature within each area was recorded continuously in shelters positioned 10 centimetres above 
ground surface. Burrow temperatures were measured periodically by telemetry employing systems described by Pauley et al. (1968) and Shirer and Downhower (1968). Two transmitters with different carrier frequencies $(27.660$ and $27.670 \mathrm{mHz})$ but with similar battery life $(4 \mathrm{mo})$ were introduced into the main burrow system of each colony. Transmitters were attached to collars on resident marmots; the marmots removed the collars within the burrow system.

In May or June each marmot was trapped, marked, weighed, sexed (Armitage 1962), and assigned to the age category of young, yearling, or adult (Downhower and Armitage 1971:357). Retrapping occurred at 2-wk intervals; $70 \%$ of the marmots were retrapped at least twice.

The daily activity patterns of individual marmots were observed directly from blinds 200 to 400 metres from the colony. Each colony was observed for at least 5 full days each month from June through September. During observation periods, which extended from before sunrise to near dark, the location and activity of each marmot was recorded at 10 -min intervals.

\section{Laboratory studies}

Food consumption measurements, from which estimates of energy intake, digested energy, and digestive efficiency were obtained, were conducted at the Rocky Mountain Biological Station in 1969 and 1970, from mid-June to mid-September. Six marmots captured in early June or July were used each year including young, yearlings, and adults of both sexes. These marmots were maintained in an unheated laboratory room at near-ambient conditions in separate cages and provided with fresh vegetation ad libitum for $1 \mathrm{wk}$ before daily measurements of food consumption and feces production began.

Following this adjustment period, each marmot was provided known amounts of Potentilla gracilis, Taraxacum officinale, Agoseris glauca, and Bromus richardsonii, in various combinations, twice daily. A sample of each plant species fed on a particular day was weighed, dried to a constant weight, and stored for subsequent determination of energy content. Controls were established at each feeding to correct for $\mathrm{H}_{2} \mathrm{O}$ loss in the plant material. Marmots were fed fresh vegetation for the duration of the measurements in 1969 and 1970 except in late August and September of 1970 when they were fed a commercial rabbit chow. Water was provided ad libitum only when commercial chow was used. Each marmot was weighed biweekly.

The total quantity of feces produced by an individual animal in a 24-h period was collected daily prior to the morning feeding. If the wet weight of the total sample was $\leqslant 200 \mathrm{~g}$, it was dried to a constant weight at $60 \pm 5^{\circ} \mathrm{C}$ (7-11 days) and stored; however, if the wet weight exceeded $200 \mathrm{~g}$, only a $50 \pm 5 \mathrm{~g}$ (wet weight) aliquot was dried.
The energy content (per gram ash-free dry weight) of both plant and fecal material was determined with a $\operatorname{Parr}^{\circledR} 1411$ calorimeter. The ash content of both materials was determined by heating samples at $600^{\circ} \mathrm{C}$ for $2 \mathrm{~h}$ (A.O.A.C. 1960).

In July 1970, 6 field-captured marmots, weighing from 0.5 to $3.4 \mathrm{~kg}$, were taken to the laboratory in Lawrence, Kansas. These marmots were kept at $20^{\circ} \pm 3^{\circ} \mathrm{C}$, under a 12 - $\mathrm{h}$ photoperiod and given laboratory chow and water ad libitum. Oxygen uptake and $\mathrm{CO}_{2}$ production of nonfasted, resting marmots were measured at air temperatures from $5^{\circ}$ to $25^{\circ} \mathrm{C}$ (corresponding to field exposure temperatures, see below).in a positive-pressure open-flow system (Depocas and Hart 1957). The difference between the fractional concentration of $\mathrm{O}_{2}$ and $\mathrm{CO}_{2}$ in the inflow and outflow air was measured with a Beckman ${ }^{\circledR} \mathrm{F} 3$ paramagnetic $\mathrm{O}_{2}$ analyzer and a Beckman ${ }^{\circledR}$ infrared analyzer (model $215 \mathrm{~A})$, respectively.

Marmots were placed in metal respirometers, $58.4 \times 36.2 \times 53.5$ centimetres, within a constant temperature chamber. Each respirometer was equipped with microswitches for detecting movement. Dry room air was passed through the respirometers at flow rates of 5.9 to 8.6 litres/min. Marmots were exposed to the respirometer temperatures for 7 to $9 \mathrm{~h}$ before $\mathrm{O}_{2}$ uptake and $\mathrm{CO}_{2}$ production were recorded. Then measurements were recorded continuously until a steady-state $\left(<5 \%\right.$ variation) $\mathrm{O}_{2}$ consumption and $\mathrm{CO}_{2}$ production was obtained for $15 \mathrm{~min}$. Steady-state values could generally be obtained within 30 to $90 \mathrm{~min}$. Because several 24-h measurements revealed no evidence of a circadian rhythm, all determinations were obtained between 1400 and $2200 \mathrm{~h}$.

Rectal temperature of marmots was measured at the termination of each metabolism experiment. A telethermometer rectal probe was inserted into the colon to a depth of 15 centimetres in adults and yearlings, 10 centimetres in young.

\section{Statistical treatment of data}

Energy flow variables were standardized for variations in animal weight. When significant relationships between these weight-specific variables and body weight existed, the significance of independent variables (i.e., sex, age, season) was determined with multivariate analysis of covariance; otherwise, significant effects of the independent variables on the mensurable energy flow variables were determined with multiple designs of analysis of variance. The significant independent variables were incorporated into multiple regression equations. Statistical significance was assumed when $P \leqslant .05$.

The univariate analyses followed the methods of Sokal and Rohlf (1969) while the multivariate analyses were portions of the BMD package of biomedical programs (Dixon 1968). 
TABLE 1. Dry weight and energy content of the aboveground living vegetation in areas ( 1 and 4 ) occupied by colonies 1 and 4 , respectively. The values are means \pm the standard error of the mean. Energy content of the standing crop was computed using the joules/ash-free gram dry weight of individual plants

\begin{tabular}{lccc}
\hline & $\begin{array}{c}\text { No. } \\
\text { of } \mathrm{m}^{2} \\
\text { plots } \\
\text { sam- }\end{array}$ & \multicolumn{2}{c}{ Standing crop } \\
\cline { 4 - 4 } Date & pled & $\mathrm{g} / \mathrm{m}^{2}$ & $\mathrm{~kJ} / \mathrm{m}^{2}$ \\
\hline Area 1 & & & \\
28 June 1970 & 10 & $201.6 \pm 28.0$ & $3492.4 \pm 427.6$ \\
14 July 1970 & 10 & $247.5 \pm 28.3$ & $3827.1 \pm 366.1$ \\
Area 4 & & & \\
6 June 1969 & 15 & $215.5 \pm 18.1$ & $4745.5 \pm 528.4$ \\
13 June 1969 & 15 & $206.1 \pm 19.5$ & $4891.1 \pm 433.9$ \\
28 June 1969 & 15 & $280.2 \pm 20.3$ & $8138.3 \pm 1526.3$ \\
16 July 1969 & 15 & $348.0 \pm 26.5$ & $11727.3 \pm 1765.2$ \\
9 August 1969 & 15 & $457.9 \pm 36.8$ & $11567.1 \pm 1874.9$ \\
\hline
\end{tabular}

\section{Results AND Discussion}

\section{Energy available to the colonies}

The growing season in the East River Valley generally extends from early June to mid-August (Barrell 1969). The mean dry weight of the aboveground standing crop of the living vegetation (grams per square metre) increased as the season progressed (Table 1). The peak standing crops were used as the minimal estimates of the aboveground net primary production (Odum 1960). The differences between the standing crops at similar times of the year generally reflect the quantitative differences in the vegetation of the 2 areas. The average energy value of the green vegetation was $20.79 \mathrm{~kJ} / \mathrm{g}$ ash-free dry weight.

In contrast to the continuous increase in the mean dry weight of the standing crop, the energy content (kilojoules per square metre) tended to stabilize in the second half of the growing season (Table 1) because of seasonal variation in the energy content of the dominant species and from changes in the species composition. Although the difference between the means on the sample dates in area 1 was not significant $(P>.05)$, there were statistically significant differences between the means in area $4(P<.001)$.

The aboveground net primary production (NP) of the vegetation was $38.28 \mathrm{GJ} \cdot \mathrm{ha}^{-1} \mathrm{yr}^{-1}$ (1 gigajoule $[\mathrm{GJ}]=10^{9}$ joules) in area 1 and $117.28 \mathrm{GJ} \cdot \mathrm{ha}^{-1} \mathrm{yr}^{-1}$ in area 4 . About $40 \%$ of the occupied area was used for feeding: $5,789 \mathrm{~m}^{2}$ by colony 1 and $7,710 \mathrm{~m}^{2}$ by colony 4. Assuming that $100 \%$ of the aboveground production in the feeding areas was accessible to marmots, the production available (AP) to the marmots in colonies 1 and 4 was $22.2 \mathrm{GJ} / \mathrm{yr}$ and $90.4 \mathrm{GJ} / \mathrm{yr}$, respectively. If the production consumed by the marmots $(1.5 \mathrm{GJ}$ per season by colony 1 and 1.84 GJ per season by colony 4 ) is added to the above values, the energy available to the colonies during their active season was $23.7 \mathrm{GJ}$ and 92.3 GJ, respectively.

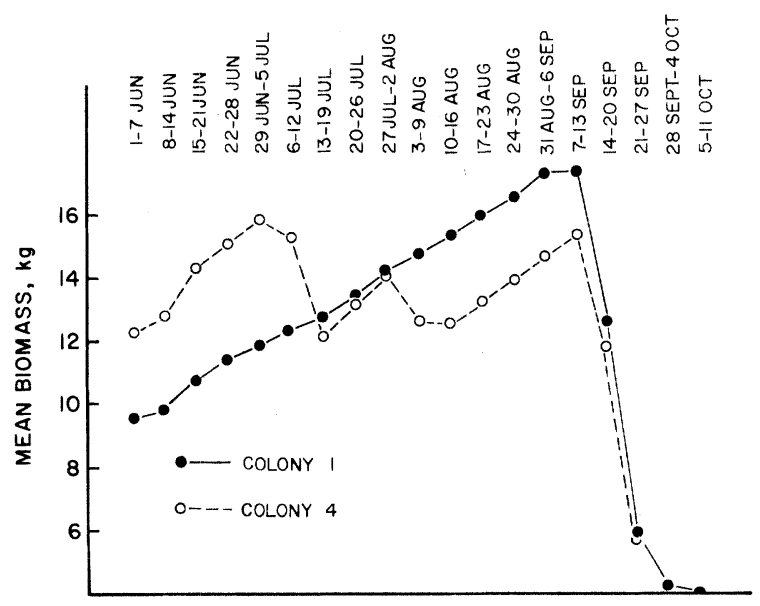

FIG. 2. Seasonal variation in the standing crop of colonies 1 and 4 . The means are based on the mean weight of all nonhibernating individuals during the week intervals. We assumed that young were born on 15 June (30 days prior to their appearance above ground), that the average birth weight was $35 \mathrm{~g}$ (J. W. Koeppl, personal communication), and that the preweening growth rate of young was $0.014 \mathrm{~kg} / \mathrm{day}$.

\section{Colony dynamics}

Population number and standing crop.-The standing crop of marmot populations varies seasonally because of immigration, emigration, and reproduction. Population density remains relatively constant until June when the young are born. Most yearlings disperse (Armitage and Downhower 1974). These fluctuations in number are related to the social behavior of marmots (Armitage 1975).

Seasonal changes in standing crop of colony 4 (Fig. 2) reflect these changes in population number. Biomass increased to a peak of $15.9 \mathrm{~kg}$ on 2 July, when the colony consisted of 3 adults ( 1 male, 2 females), 4 yearlings ( 1 male, 3 females) and 5 young ( 3 males, 2 females). The standing crop declined when 3 yearlings emigrated on 10 July; 1 yearling emigrated on 2 August but returned for 2 days in September. Two adults entered hibernation on 16 September; the postpartum adult female and the young remained active until 23 September. The mean standing crop of colony 4 was $13.3 \mathrm{~kg}$ or $0.7 \mathrm{~g} / \mathrm{m}^{2}$. Density is based on the area used by the colony, "colony home range," which was 1.94 ha.

The pattern of seasonal change in standing crop of colony 1 differs markedly from that in colony 4 (Fig. 2 ). No young were produced in colony 1 in 1969; therefore, there were no yearlings in the colony in 1970. The colony consisted of 4 adults ( 1 male, 3 females) until 15 June when 3 young ( 1 male, 2 females) were born. Biomass increased to a maximum of $17.4 \mathrm{~kg}$ on 10 September. The adult male and nonreproductive females hibernated between 11-17 September. The adult female with the litter was active until 23 September, while the young remained active until 5 October. The mean standing crop of colony 1 was $12.0 \mathrm{~kg}$ or $0.9 / \mathrm{g} \mathrm{m}^{2}$ (colony home range was $1.27 \mathrm{ha}$ ). 
TABLE 2. Growth coefficients $(b)$ of captive and free-ranging marmots in kilograms/day. The field marmots are those in colonies 1 and 4 in both 1969 and 1970

\begin{tabular}{|c|c|c|c|c|}
\hline \multirow[b]{2}{*}{ Sex } & \multicolumn{2}{|c|}{ Field } & \multicolumn{2}{|c|}{ Captive } \\
\hline & $b$ & $\mathrm{~N}^{\mathrm{a}}$ & $b$ & $\mathrm{~N}^{\mathrm{a}}$ \\
\hline $\begin{array}{l}\text { Adult } 00 \\
\text { Adult } \$ 9 \text { (without litters) } \\
\text { Adult } \$ 9 \text { (with litters) }\end{array}$ & $\begin{array}{l}.015 \\
.013 \\
.005\end{array}$ & $\begin{array}{r}(12: 5) \\
(17: 4) \\
(9: 3)\end{array}$ & $\begin{array}{l}.011 \\
.006\end{array}$ & $\begin{array}{l}(25: 3) \\
(15: 2)\end{array}$ \\
\hline $\begin{array}{l}\text { Yearling } 000 \\
\text { Yearling } 9 \\
\end{array}$ & $\begin{array}{l}.013 \\
.009\end{array}$ & $\begin{array}{r}(5: 4) \\
(10: 5)\end{array}$ & $\begin{array}{l}.013 \\
.010\end{array}$ & $\begin{array}{r}(9: 1) \\
(19: 2)\end{array}$ \\
\hline $\begin{array}{l}\text { Young of } 0 \\
\text { Young } 9 \text { क }\end{array}$ & $\begin{array}{l}.017 \\
.014\end{array}$ & $\begin{array}{l}(29: 6) \\
(39: 7)\end{array}$ & $\begin{array}{l}.020 \\
.011\end{array}$ & $\begin{array}{r}(4: 1) \\
(18: 2)\end{array}$ \\
\hline
\end{tabular}

a (number of observations: number of animals).

Growth.-Free-ranging and captive marmots gained weight at a nearly constant rate during the active season with the exception of some adults and yearlings who initially lost weight following confinement and of some free-ranging adults who lost weight prior to hibernating. The loss of weight by free-ranging animals is uncommon and is associated with mortality during hibernation (Armitage et al. 1976). Weight gain was not partitioned into fat deposition or production of other new tissue.

Free-ranging marmots in the 3 age groups gained weight at similar rates (Table 2). Growth rates of males and females were similar, except that females producing litters gained weight significantly slower $(P<.05)$ than their nonreproductive counterparts.

The growth rates of captive marmots were not significantly different $(P>.05)$ from those of free-ranging animals, except captive adult females gained weight significantly slower $(P<.05)$ than nonbreeding freeranging females (Table 2 ).

\section{Population energy flow}

Intake-Rejecta model: $E_{F}=E_{I}-E_{F U}$.-Energy intake (kilojoules per kilogram per day) of captive yellow-bellied marmots varied with age and sex of the animal and with season (Table 3). Within each age group, males generally have higher intake than females and there is a decline in energy intake in September. A similar seasonal trend in food consumption was observed in captive woodchucks (Fall 1971).

Body weight is negatively related $(P<.001)$ to weight-specific energy intake in the total sample; consequently, young marmots have a higher intake per unit weight than adults. The same relationship exists within adults $(P<.01)$ and yearlings $(P<.001)$ but not within young. The sexual and seasonal differences in mean energy intake within adults (body weight difference adjusted by analysis of covariance) are statistically significant $(P<.001)$. Within yearlings, only seasonal differences were significant $(P<.001)$. The mean energy intake of young males $\left(1651.0 \mathrm{~mJ} \cdot \mathrm{kg}^{-1}\right.$ day $\left.^{-1}\right)$ did not differ significantly $(P>.05)$ from that of young females $\left(1417.5 \mathrm{~kJ} \cdot \mathrm{kg}^{-1} \mathrm{day}^{-1}\right)$. Season $\mathrm{did}$ not significantly affect the energy intake of young animals.

The above analysis of energy intake of captive marmots was used to generate the following multiple regression equations to predict $\mathrm{E}_{\mathrm{I}}$ of free-ranging marmots:

Adult males, $\quad \mathrm{E}_{\mathrm{I}}=1090.52-390.76 \mathrm{~W}+3.89 \mathrm{D} ;$

Adult females, $E_{I}=671.80-202.96 \mathrm{~W}+0.76 \mathrm{D}$;

Yearlings, $\quad \mathrm{E}_{\mathrm{I}}=333.41-1.35 \mathrm{D}$;

Young, $\quad \mathrm{E}_{\mathrm{I}}=355.83$.

In these equations, $\mathrm{W}$ is body weight in kilograms and $\mathrm{D}$ is the number of days past 1 June. Only the independent variables that were significantly related to weight-specific energy intake, i.e., $b_{\mathrm{i}}>0$, were included in these equations.

The energy ingested by an individual marmot on a particular day was predicted from its body weight, which was obtained from an allometric equation relating weight to time. Energy values so obtained were summed for the colony by age group and month (Kilgore 1972). The total energy intake of colony 1 in 1970 was $1512.9 \mathrm{MJ}$ ( 1 megajoule $=10^{6}$ joules $)$ and that of colony 4 in 1969 was $1835.9 \mathrm{MJ}$.

The ratio between energy digested (intake minus the energy lost in feces) and energy intake represents the efficiency of digestion (Petrusewicz and Macfadyen 1970). Digestive efficiency decreased with progression of the season, except in young males (Table 4). Digestive efficiency varies with energy intake and with body weight (Petrusewicz and Macfadyen 1970). Digestive efficiency was positively $(P<.001)$ correlated with total energy intake (kilojoules per day) and negatively $(P<.05)$ correlated with body weight for all individuals considered together or within each age group.

TABLE 3. Weight-specific energy intake (kilojoules per kilogram per day) in captive yellow-bellied marmots. The values are means \pm the standard error of the mean; data for 1969 and 1970 are pooled. Sample sizes for the means are the numbers in parentheses. $N$ is the number of animals in each category

\begin{tabular}{|c|c|c|c|c|c|}
\hline Sex & $N$ & June & July & August & September \\
\hline Adult $\sigma \sigma$ & 3 & $662.3 \pm 65.7(18)$ & $1133.9 \pm 43.1$ & $1278.6 \pm 45.6$ & $840.6 \pm 39.3$ \\
\hline Adult $\subsetneq \wp$ & 2 & $545.6 \pm 48.1(17)$ & $894.5 \pm 75.3$ & $1082.8 \pm 26.4$ & $674.5 \pm 54.0$ \\
\hline Yearling $\delta \widehat{\sigma}$ & 1 & $1230.1 \pm 98.7(10)$ & $1079.1 \pm 66.5$ & $1066.9 \pm 66.1$ & $1083.7 \pm 65.3$ \\
\hline Yearling 우 우 & 2 & $944.3 \pm 90.4(14)$ & $1256.9 \pm 33.9$ & $1106.7 \pm 44.4$ & $645.2 \pm 45.2$ \\
\hline Young of $\delta$ & 1 & & $1243.5 \pm 208.8$ & $1768.2 \pm 128.0(20)$ & $1091.2 \pm 229.7$ \\
\hline Young $q$ 웅 & 2 & & $929.7 \pm 188.3$ & $1707.1 \pm 100.8(12)$ & $1369.8 \pm 77.8$ \\
\hline
\end{tabular}


TABLE 4. Digestive efficiency (energy digested/energy intake $\times 100$ ) of caged yellow-bellied marmots. The values are means \pm the standard error of the mean and the numbers in parentheses are the sample sizes for the means. The means are unadjusted for variations in energy intake $(\mathrm{kJ} / \mathrm{day})$ and body weight

\begin{tabular}{|c|c|c|c|c|}
\hline Sex & June & July & August & September \\
\hline Adult $\delta \sigma^{\star}$ & $78.86 \pm 1.43(10)$ & $84.19 \pm 1.81(10)$ & $56.34 \pm 5.40$ & $43.52 \pm 6.04$ \\
\hline Adult $q$ ? & $82.01 \pm 2.45$ & $79.89 \pm 2.63$ & $70.12 \pm 5.12$ & $45.27 \pm 5.67$ \\
\hline Yearling $\delta 0$ & $73.05 \pm 3.30$ & $75.59 \pm 1.49(10)$ & $75.01 \pm 3.66(10)$ & $62.73 \pm 6.81$ \\
\hline Yearling $q q$ & $72.69 \pm 2.26(10)$ & $82.12 \pm 1.08(10)$ & $68.33 \pm 5.45(10)$ & $50.87 \pm 8.24$ \\
\hline Young oे 0 & & $79.08 \pm 8.67$ & $78.06 \pm 2.22(10)$ & $84.74 \pm 16.70$ \\
\hline Young $q 9$ & & $64.13 \pm 4.78$ & $48.58 \pm 6.31$ & $36.71 \pm 5.02$ \\
\hline
\end{tabular}

Analysis of covariance revealed that digestive efficiency was significantly affected by season (adults and yearlings, $P<.05$ ) and sex (yearlings, $P<.05$; young, $P<.001)$ (Kilgore 1972).

Energy intake $\left(E_{\mathrm{I}}\right)$, body weight $(\mathrm{W})$, and time (D) were included in multiple regression equations to predict digestive efficiency (DE) in free-ranging marmots:

$$
\begin{array}{lrl}
\text { Adults, } & \mathrm{DE}=126.55+0.02 \mathrm{E}_{\mathrm{I}} \\
& -18.17 \mathrm{~W}-0.37 \mathrm{D} ; \\
\text { Yearling males, }, & \mathrm{DE}=55.84+0.05 \mathrm{E}_{\mathrm{I}} ; \\
\text { Yearling females, } & \mathrm{DE}=58.50+0.06 \mathrm{E}_{\mathrm{I}}-0.29 \mathrm{D} ; \\
\text { Young males, } & \mathrm{DE}=66.31+0.04 \mathrm{E}_{\mathrm{I}} ; \\
\text { Young females, }, & \mathrm{DE}=84.05+0.08 \mathrm{E}_{\mathrm{I}}-0.70 \mathrm{D} .
\end{array}
$$

The portion of $E_{I}$ digested was determined daily and summed by age group and month (Kilgore 1972). Colony 1 digested $72 \%$ or $1091.6 \mathrm{MJ}$ of the $1512.9 \mathrm{MJ}$ ingested; colony 4 digested $76.5 \%$ or $1404.5 \mathrm{MJ}$ of the 1835.9 MJ ingested.

The proportion of digested energy excreted in the urine of free-ranging or captive marmots was estimated from urine production and urinary nitrogen excretion in nonhibernating woodchucks (Marmota monax). Active, nonfasted woodchucks lost $0.5 \mathrm{~g}$ urinary $\mathrm{N} \cdot \mathrm{kg}^{-1} \cdot \mathrm{day}^{-1}$ (Benedict and Lee 1938 ); hence, we assumed that the average marmot $(2.36 \mathrm{~kg})$ excreted $1.18 \mathrm{~g} \mathrm{~N}$ daily. Since $>90 \%$ of the urinary $\mathrm{N}$ excreted by woodchucks is in urea and since the energy equiva- lent of urea is $22.6 \mathrm{~kJ} / \mathrm{g}$ (Kleiber 1961:262), the average marmot lost $26.7 \mathrm{~kJ} /$ day in urine. The urinary energy lost by colony 1 during the active season was $19.5 \mathrm{MJ}$. Colony 4 lost $23.7 \mathrm{MJ}$.

Seasonal energy flow based on this model was 1071.9 MJ in colony 1 and $1380.3 \mathrm{MJ}$ in colony 4 (Table 5). These energy flow quantities represent $71 \%$ and $75 \%$ of the energy ingested by the colonies, respectively.

Maintenance-Production model, $E_{F}=E_{R}+E_{P}$.The daily activity pattern of marmots is temperature dependent (Armitage 1962, 1965; Travis and Armitage 1972). The temperature near ground level in areas 1 and 4 varied from -4 to $28^{\circ} \mathrm{C}$ and from -8 to $29^{\circ} \mathrm{C}$, respectively, but marmots were never aboveground when the temperature was $<1.2^{\circ} \mathrm{C}$ or $>26.4^{\circ} \mathrm{C}$. Air temperature rarely reaches $25^{\circ} \mathrm{C}$. Burrow temperatures varied from 8.6 to $11.5^{\circ} \mathrm{C}$. Mean burrow temperature, lagging the seasonal increase in air temperature by $\approx 1 \mathrm{mo}$ (Kilgore 1972), increased from $9.0^{\circ} \mathrm{C}$ in June to $11.3^{\circ} \mathrm{C}$ in late August, then declined to $9.3^{\circ} \mathrm{C}$ in late September and $9.1^{\circ} \mathrm{C}$ in early October.

The weight-specific metabolic rate of nonfasted marmots at rest $\left(\mathrm{M}_{\text {rest }}\right.$ of Eq. $\left.1 a\right)$ is inversely proportional to air temperature $<25^{\circ} \mathrm{C}$ (Fig. 1). When the metabolic data for all individuals are adjusted for the

\begin{tabular}{|c|c|c|c|c|c|c|}
\hline \multirow[b]{2}{*}{ Models and parameters } & \multicolumn{3}{|c|}{ Colony 1} & \multicolumn{3}{|c|}{ Colony 4} \\
\hline & MJ & $\mathrm{kJ} / \mathrm{m}^{2}$ & $\%$ & MJ & $\mathrm{kJ} / \mathrm{m}^{2}$ & $\%$ \\
\hline \multicolumn{7}{|l|}{ Intake-Rejecta model } \\
\hline Intake $\left(\mathrm{E}_{\mathrm{I}}\right)$ & 1512.9 & 119.2 & 100.0 & 1835.9 & 94.6 & 100.0 \\
\hline Feces $\left(E_{F}\right)$ & 421.3 & 33.1 & 27.8 & 431.8 & 22.2 & 23.5 \\
\hline Urine $\left(E_{U}\right)$ & 19.7 & 1.7 & 1.3 & 23.8 & 1.3 & 1.3 \\
\hline Energy flow $\left(E_{F}\right)$ & 1071.9 & 84.5 & 70.9 & 1380.3 & 71.1 & 75.2 \\
\hline \multicolumn{7}{|c|}{ Maintenance-Production model } \\
\hline Maintenance $\left(\mathrm{E}_{\mathrm{R}}\right)$ & 704.6 & 55.2 & 58.7 & 771.9 & 39.7 & 62.3 \\
\hline Production $\left(\mathrm{E}_{\mathrm{p}}\right)$ & 496.2 & 39.2 & 41.3 & 466.9 & 24.1 & 37.6 \\
\hline Growth $\left(\mathrm{E}_{\mathrm{g}}\right)$ & 492.9 & 38.9 & 41.0 & 461.4 & 23.8 & 37.2 \\
\hline Reproduction $\left(\mathrm{E}_{\mathrm{r}}\right)$ & 3.3 & 0.25 & 0.3 & 5.4 & 0.25 & 0.4 \\
\hline Energy flow $\left(E_{F}\right)$ & 1200.8 & 94.6 & 100.0 & 1238.9 & 64.0 & 100.0 \\
\hline Mean energy flow & 1136.4 & 89.5 & & 1309.5 & 67.4 & \\
\hline
\end{tabular}
significant relationship between body weight and weight-specific metabolic rate $(P<.001)$ and the significant $(P<.001)$ first-order interaction between

TABLE 5. Summary of seasonal energy flow in 2 populations of yellow-bellied marmots. Colony home ranges: colony $1,1.272$ ha; colony $4,1.945$ ha 
age-sex groups and air temperature (i.e., the dissimilarity of slopes), the differences between age-sex groups and between air temperatures are significant $(P<.05)$. Adjusted metabolic rates of males are lower than those of females; those of adult females are lower than those of young females $(P<.05)$. In calculating $\mathrm{E}_{\mathrm{m} 1}$ (Eq. $1 b$ ) for yearling females and young males the regression equations of their sexual counterparts were used. No animals became torpid; minimal body temperature was $36.1^{\circ} \mathrm{C}$.

The metabolic rate of nonfasted adult and yearling marmots is $\approx 70 \%$ of that predicted from body weight. For example, the metabolic rate of a $2.5 \mathrm{~kg}$ nonfasted marmot should approximate $13.8 \mathrm{~J} \cdot \mathrm{g}^{-1} \cdot \mathrm{h}^{-1}$ (Kleiber 1961:212, 274; Benedict and Lee 1938); however, the observed mean value (at $20^{\circ} \mathrm{C}$ ) was $9.6 \mathrm{~J} \cdot \mathrm{g}^{-1} \cdot \mathrm{h}^{-1}$.

Colony 1 expended $92.7 \%$ of $\mathrm{E}_{\mathrm{R}}$ while the animals were at rest $\left(\mathrm{E}_{\mathrm{m} 1}\right)$ above and below ground (Table 6); similarly colony 4 expended $92 \%$ of $E_{R}$ at rest.

The relatively small proportion of the maintenance energy that can be attributed to moderate activity $\left(\mathrm{E}_{\mathrm{m} 2}\right)$ and locomotion $\left(\mathrm{E}_{\mathrm{m} 3}\right)$ (Table 6) is a direct reflection of the absolute time marmots were aboveground and active. Individual marmots averaged $16 \%$ of any 24-h period or $230 \mathrm{~min}$ aboveground (the maximum time in both colonies was $500 \mathrm{~min}$ ), but were engaged in some form of activity (moderate or locomotion) $<50 \%$ of this time. We assumed animals rested when underground. In all age groups, except adults of colony 1 , aboveground time and activity increased as the season progressed and then decreased preceding hibernation; the time adults of colony 1 were aboveground progressively declined with time. There were similar seasonal patterns (Kilgore 1972) in the distances traversed by marmots during locomotory periods (d values: Eq. $3 b$ ).

The secondary production of colonies 1 and 4 was 496.2 MJ and 466.9 MJ, respectively (Table 5). Growth and fat deposition in marmots accounted for $\approx 99 \%$ of the population production $(99.3 \%$ in colony 1 and $98.8 \%$ in colony 4 ).

Energy flow during the active season was $1200.8 \mathrm{MJ}$ in colony 1 and $1238.9 \mathrm{MJ}$ in colony 4.

\section{Comparison of Models and Populations}

\section{Energy flow in active season}

Estimates of colony energy flow (MJ per active season) based on the 2 independent models are similar (Table 5). The difference between estimates is $10.7 \%$ in colony 1 and $10.2 \%$ in colony 4 . Considering the errors inherent in these predictive models, it would appear that either model provides a reasonable estimate of population energy flow.

The agreement between estimates is partially predetermined. Because predictions of the energy flow parameters in both models are directly based on body weight, they should yield similar results. More importantly, the independently derived estimates should be
TABLE 6. Proportions $(\%)$ of the seasonal maintenance energy of colonies 1 and 4 (704.6 MJ and $771.9 \mathrm{MJ}$, respectively) that can be attributed to the 3 activity levels

\begin{tabular}{lcc}
\hline $\begin{array}{l}\text { Location and } \\
\text { activity level }\end{array}$ & Colony 1 & Colony 4 \\
\hline Aboveground & & \\
$\quad$ Rest & 8.0 & 8.2 \\
Moderate activity & 6.5 & 7.5 \\
$\quad$ Locomotion & 0.8 & 0.5 \\
In burrow & & \\
$\quad$ Rest & 84.7 & 83.8 \\
\hline
\end{tabular}

reasonably accurate as they are based on populations of known size and biomass and as variations in the energy flow parameters resulting from a number of independent variables were incorporated in the models.

The clumped distribution of marmots imposes limitations on the significance of energy flow expressed per unit area. However, if colony home range is used, mean energy flow was 67.4 and $89.5 \mathrm{~kJ}$ per $\mathrm{m}^{2}$ per season (Table 5). Daily energy flow during the 1969 and 1970 seasons was, respectively, 0.50 and 0.67 $\mathrm{kJ} / \mathrm{m}^{2}$.

The $22.1 \mathrm{~kJ} / \mathrm{m}^{2}$ difference between colonies 1 and 4 in mean energy flow (Table 5) results primarily from the difference in standing crop of the 2 populations. The mean seasonal biomass per unit area of colony 1 was $9 \times 10^{-4} \mathrm{~kg} / \mathrm{m}^{2}$ while that of colony 4 was $7 \times 10^{-4}$. Expressed per unit biomass the energy flow of both colonies is nearly identical (colony 1: 99.6 $\mathrm{MJ} / \mathrm{kg}$, colony 4: $96.2 \mathrm{MJ} / \mathrm{kg}$ ).

The peak energy flow in colony 1 occurred in August, while that of colony 4 occurred in June. This difference in time of the peak energy flow results from seasonal changes in biomass of the populations (Fig. 2) which are related to the reproductive performance of the population in the previous year (Armitage and Downhower 1974). The primary difference in the patterns of standing crop is the presence of yearlings. In 1969 no young were produced in colony 1 ; hence, there were no yearlings in 1970. The pattern of energy flow and standing crop of colony 4 is probably more representative of marmot colonies in general (Armitage and Downhower 1974).

\section{Annual energy flow}

There is a marked contrast between energy flow in marmot colonies during the active season and that in hibernation. Because marmots do not consume food during hibernation, only a modified form of the Maintenance-Production model is applicable.

Energy use during hibernation may be estimated from loss of body weight. Colonies 1 and 4 lost $8.25 \mathrm{~kg}$ and $7.52 \mathrm{~kg}$ during mean hibernating periods of 239 and 242 days, respectively. We assume that the partitioning of weight loss is similar to that of hibernating arctic 
TABLE 7. Summary of annual energy flow in 2 populations of yellow-bellied marmots. See Table 5 for colony home ranges

\begin{tabular}{|c|c|c|c|c|c|c|}
\hline \multirow[b]{2}{*}{ Model and parameter } & \multicolumn{3}{|c|}{ Colony 1} & \multicolumn{3}{|c|}{ Colony 4} \\
\hline & MJ & $\mathrm{kJ} / \mathrm{m}^{2}$ & $\%$ & MJ & $\mathrm{kJ} / \mathrm{m}^{2}$ & $\%$ \\
\hline \multicolumn{7}{|c|}{ Maintenance-Production model } \\
\hline Maintenance $\left(E_{R}\right)$ & 917.1 & 72.0 & 76.4 & 964.4 & 49.8 & 77.8 \\
\hline Production $\left(\mathrm{E}_{\mathrm{p}}\right)$ & 283.7 & 22.4 & 23.6 & 274.1 & 14.1 & 22.1 \\
\hline Growth $\left(\mathrm{E}_{\mathrm{g}}\right)$ & 280.3 & 22.2 & 23.3 & 268.6 & 13.8 & 21.7 \\
\hline Reproduction $\left(\mathrm{E}_{\mathrm{r}}\right)$ & 3.3 & 0.25 & 0.3 & 5.4 & 0.25 & 0.4 \\
\hline Energy flow $\left(\mathrm{E}_{\mathrm{F}}\right)$ & 1200.8 & 94.6 & 100.0 & 1238.9 & 64.0 & 100.0 \\
\hline
\end{tabular}

ground squirrels (Spermophilus parryi); i.e., $62 \%$ as lipid and $9 \%$ as protein (Galster and Morrison 1975). Using energy equivalents of $38.1 \mathrm{~kJ} / \mathrm{g}$ for lipid and 23.8 $\mathrm{kJ} / \mathrm{g}$ for protein (Kleiber 1961:125), we estimate that colony 1 expended 212.5 MJ and colony 4, 192.5 MJ as $\mathrm{E}_{\mathrm{R}}$ during hibernation. The values are $30 \%$ and $25 \%$ of the maintenance energy expended during the active season and emphasize the considerable energy savings that otherwise would be expended for maintenance if the animals were normothermic throughout the year.

There is no difference between seasonal (Table 5) and annual energy flow (Table 7); however, proportional relationships differ. Annual secondary production in colony 1 represents only $23.6 \%$ of the total energy flow, but $41.3 \%$ of the seasonal energy flow. Less than $2.0 \%$ of $E_{p}$ was used as $E_{r}$ (Table 7); most small mammals use $>50 \%$ as $\mathrm{E}_{\mathrm{r}}$ (Petrusewicz and Hansson 1975).

The difference between active season and annual energy flow emphasizes the problem of treating all weight increase as production. Fat deposition is treated as production; its subsequent use then must be considered negative production. The calculation of an annual budget eliminates the problem of negative production. However, monthly or seasonal budgets reveal patterns of resource utilization that are obscured or missed when only annual budgets are calculated. To whatever degree fattened marmots are prey (or die from other causes), the production is passed on to other trophic levels. Thus, there seems to be no easy alternative when describing energy budgets of animals that store energy as body tissue except to consider weight loss as negative production $\left(\mathrm{E}_{\mathrm{R}}>\mathrm{E}_{\mathrm{A}}\right)$.

\section{Comparisons with other mammals}

Direct comparisons of population energy flow will not answer the question of how energy flow in populations of hibernators differs from that in nonhibernating mammals since population energy flow is a function of population density and size of individuals. However, comparisons of ratios between annual energy flow parameters should elucidate differences between populations of classical hibernators and nonhibernating mammals, if differences exist. Of particular interest is the efficiency with which the populations utilize the primary production, assimilate ingested energy, and convert assimilated energy into production.
The efficiency with which marmot populations used the net aboveground primary production $\left(\mathrm{E}_{\mathrm{I}} / \mathrm{NP}\right)$ was $0.8 \%\left(94.6 / 11728 \mathrm{~kJ} \cdot \mathrm{m}^{-2} \cdot \mathrm{yr}^{-1} \times 100\right)$ and $3.1 \%$ $\left(119.2 / 3828 \mathrm{~kJ} \cdot \mathrm{m}^{-2} \cdot \mathrm{yr}^{-1} \times 100\right)$. These values are within the range of efficiencies reported for other mammal populations (Chew and Chew 1970).

Because only a fraction of the net primary production is available to most species populations, a more meaningful ratio is the efficiency with which a population utilizes the available net primary production (AP), $\left(E_{\mathrm{I}} / \mathrm{AP}\right)$. The efficiency of marmot populations in exploiting AP was $2 \%(1836.0 \mathrm{MJ} / 92.3 \mathrm{GJ} \times 100)$ and $6.4 \%(1512.9 \mathrm{MJ} / 23.7 \mathrm{GJ} \times 100)$, which is comparable to the efficiencies of nonhibernating mammal populations of similar density and utilizing similar foods (Chew and Chew 1970, Golley et al. 1975).

The relatively low $\mathrm{E}_{\mathrm{I}} / \mathrm{AP}$ efficiency of marmot populations suggests that population density in marmots is not strictly limited by food. Nevertheless, Downhower and Armitage (1971:363) postulated that the number of young produced by each female each year is determined by the availability of food during gestation. They reasoned that limited food forced marmots to increase their home range thereby increasing the frequency of agonistic encounters between adult females, which adversely affect their reproductive success.

Our results do not support this postulate. During gestation, colonies 1 and 4 ingested only 1 to $2 \%$ of the net primary production available to them, assuming that the forage area was $5,789 \mathrm{~m}^{2}$ for colony 1 and 7,710 $\mathrm{m}^{2}$ for colony 4 . Even if marmots restricted their activities to 0.1 of this area, they would still ingest only 10 to $21 \%$ of the live standing crop of area 4 on 6 June. If the available net production had been only the lowest standing crop value recorded in the 2 areas and population $\mathrm{E}_{\mathrm{I}}$ had remained the same, a maximal efficiency of only $40.5 \%$ can be realized. These data suggest that even when the standing crop of vegetation is low, population density in marmots is probably not restricted by availability of food. However, at higher elevations where snow cover persists much longer, reproductive success of individual females, but not population density, may be limited by AP (Andersen et al. 1976).

The assimilation efficiency $\left(\mathrm{E}_{\mathrm{F}} / \mathrm{E}_{\mathrm{I}}\right)$ of marmot populations, $71 \%(1071.9 / 1512.9 \mathrm{MJ} \times 100)$ and $75 \%(1380.3 /$ $1836.0 \mathrm{MJ} \times 100)$, is similar to that of other rodents, but 
higher than the mean of grazing herbivores (Grodzinski and Wunder 1975). In contrast, phytophagous invertebrates assimilate only 25 to $35 \%$ of the energy they ingest (Wiegert and Evans 1967).

Homeotherms characteristically use $98 \%$ of their assimilated energy in maintenance $\left(E_{R} / E_{F}\right)$, while poikilotherms use <90\% (Golley 1968; McNeill and Lawton 1970). Marmot populations expended $76 \%$ $(917.1 / 1200.8 \mathrm{MJ} \times 100)$ and $78 \% \quad(964.4 / 1238.9$ $\mathrm{MJ} \times 100)$ of their assimilated energy in maintenance. Tissue growth efficiency $\left(E_{\mathrm{P}} / \mathrm{E}_{\mathrm{F}}\right)$ (Kozlovsky 1968) of marmots, $23.6 \%(283.7 / 1200.8 \mathrm{MJ} \times 100)$ and $22.1 \%$ $(274.1 / 1238.9 \mathrm{MJ} \times 100)$, exceeds the 1.5 to $2.5 \%$ reported for mammalian herbivores (Wiegert and Evans 1967; Chew and Chew 1970), but is considerably less than that of herbivorous insect populations, 37 to $42 \%$ (Wiegert and Evans 1967). The ecological growth efficiency $\left(\mathrm{E}_{\mathrm{A}} / \mathrm{E}_{\mathrm{I}}\right)$ (Kozlovsky 1968) of marmot popula. tions, $18.8 \%(283.7 / 1512.9 \mathrm{MJ} \times 100)$ and $14.9 \%$ $(274.1 / 1835.9 \mathrm{MJ} \times 100)$, also exceeds the $1.7 \%$ to $3.1 \%$ of nonhibernating mammals (Chew and Chew 1970). The production/maintenance ratio in marmots, $30.9 \%(283.7 / 917.1 \mathrm{MJ} \times 100)$ and $28.4 \%(274.1 / 964.4$ $\mathrm{MJ} \times 100)$, greatly exceeds the 1.1 to $3.0 \%$ typical of homeotherms and lies within the $4.3 \%$ to $42.8 \%$ range for long-lived poikilotherms (McNeill and Lawton 1970).

The marked differences in the respiration efficiencies, tissue growth efficiencies, and production/ maintenance ratios between the heterothermic marmot and typical homeotherms suggest that the adaptive strategy of some hibernators includes shifting energy from respiration into production. This shift may be possible because respiration is less than that predicted from body weight. The production/maintenance ratios calculated for the active season only are $70.4 \%(496.2 /$ $704.6 \times 100)$ and $60.5 \%(466.9 / 771.9 \times 100)$. Thes $\rightarrow$ values support the suggestion that a lowered metabolism permits a greater proportion of assimilated energy to be used in production.

Several authors formulated equations relating production and respiration ratios to modes of thermoregulation (e.g., Golley 1968; McNeill and Lawton 1970). If, using the equations formulated by McNeill and Lawton (1970) for poikilotherms, $\log R=1.0733 \log$ $\mathrm{P}+0.3757$, and homeotherms, $\log \mathrm{R}=0.9812 \log$ $\mathrm{P}+1.7418$, where $\mathrm{R}$ and $\mathrm{P}$ are maintenance metabolism and secondary productivity in $\mathrm{kJ} \cdot \mathrm{m}^{-2} \cdot \mathrm{yr}^{-1}$, respectively, one predicts a maintenance cost for marmot populations of 757 to 1197 if marmots are $\rightarrow$ homeotherms and 36.4 to 60.2 if marmots are poikilotherms. The observed values, 49.8 and 72.0 (Table 7), closely approximate those for poikilotherms. These findings demonstrate the caution that must be used in adopting short-cut methods for predicting energy flow when either $\mathrm{R}$ or $\mathrm{P}$ is known.

To return to the original questions asked in this study, patterns of annual energy flow in at least one hibernator substantially differ from those in nonhibernating mammals.

\section{ACKNOWLEDGMENTS}

Robert M. Chew, Robert S. Hoffmann, Gary C. Packard and Orley R. Taylor read various forms of the manuscript and offered many useful suggestions. We are particularly grateful to David Pippitt and Gary Worthen for assisting with laboratory and field measurements and to RMBL for field facilities.

Computer time was provided by grants from the University of Kansas $(1924,2580)$ and Duke University (DU. D26. AD1565) while the overall project was supported by NSF grants GB6123 and GB8526 awarded to Armitage. Portions of the manuscript were written while Kilgore was supported by a research grant awarded to Knut Schmidt-Nielsen (NIH HL02228).

\section{Literature Cited}

Andersen, D. C., K. B. Armitage, and R. S. Hoffmann. 1976. Socioecology of marmots: female reproductive strategies. Ecology 57:552-560.

Armitage, K. B. 1962. Social behaviour of a colony of the yellow-bellied marmot (Marmota flaviventris). Anim. Behav. 10:319-331.

$\longrightarrow \rightarrow 1965$. Vernal behaviour of the yellow-bellied marmot (Marmota flaviventris). Anim. Behav. 13:59-68.

$\rightarrow \rightarrow$ 1974. Male behaviour and territoriality in the yellow-bellied marmot. J. Zool. London 172:233-265.

$\rightarrow-$. 1975. Social behavior and population dynamics of marmots. Oikos 26:341-354.

Armitage, K. B., and J. F. Downhower. 1974. Demography of yellow-bellied marmot populations. Ecology 55:12331245 .

Armitage, K. B., J. F. Downhower, and G. E. Svendsen. 1976. Seasonal changes in weights of marmots. Am. Midl. Nat. 96:36-51.

Association of Official Agricultural Chemists (A.O.A.C.). 1960. Official methods of analysis. Washington, D.C. 832 p.

Barrell, J. 1969. Flora of the Gunnison Basin. Natural Land Institute, Rockford, Illinois. $494 \mathrm{p}$.

Benedict, F. G., and R. C. Lee. 1938. Hibernation and marmot physiology. Carnegie Institution of Washington Publ. No. 497. Waverly Press, Inc., Baltimore, Maryland. 239 p.

Chew, R. M., and E. Chew. 1970. Energy relationships of the mammals of a desert shrub (Larrea tridentata) community. Ecol. Monogr. 40:1-21.

Depocas, F., and J. S. Hart. 1957. Use of the Pauling oxygen analyzer for measurement of oxygen consumption of animals in open-circuit systems and in a short-lag, closedcircuit apparatus. J. Appl. Physiol. 10:388-392.

Dixon, W. J. 1968. Biomedical computer programs. Univ. California Publ. Automatic Computation No. 2, Univ. California Press, Berkeley. 600 p.

Downhower, J. F., and K. B. Armitage. 1971. The yellowbellied marmot and the evolution of polygamy. Am. Nat. 105:355-370.

$\rightarrow$ Ehrlich, P. R., D. E. Breedlove, P. F. Brussard, and M. A. Sharp. 1972. Weather and the "regulation" of subalpine populations. Ecology 53:243-247.

Fall, M. W. 1971. Seasonal variations in the food consumption of woodchucks (Marmota monax). J. Mammal. 52:370-375.

$\rightarrow$ Galster, W., and P. Morrison. 1975. Seasonal changes in body composition of the arctic ground squirrel, Citellus undulatus. Canadian J. Zool. 54:74-78.

Golley, F. B. 1967. Methods of measuring secondary productivity in terrestrial vertebrate populations, p. 99-124. In K. Petrusewicz [ed.] Secondary productivity of terrestrial ecosystems, Vol. 1. Panstwowe Wydawnictwo Naukowe, Warsaw. 
$\rightarrow-$ 1968. Secondary productivity in terrestrial cor munities. Am. Zool. 8:53-59.

Golley, F. B., L. Ryszkowski, and J. T. Sokur. 1975. Th role of small mammals in temperate forests, grasslands and cultivated fields. p. 223-241. In F. B. Golley, K. Petrusewicz, and L. Ryszkowski [eds.] Small mammals: their productivity and population dynamics. Cambridge Univ. Press, New York.

$\rightarrow$ Gorecki, A. 1965. Energy values of body in small mammals. Acta Theriol. 10:333-352.

Grodzinski, W., and A. Gorecki. 1967. Daily energy budgets of small rodents, p. 295-314. In K. Petrusewicz [ed.] Secondary productivity of terrestrial ecosystems, Vol. 1. Panstwowe Wydawnictwo Naukowe, Warsaw.

Grodzinski, W., and B. A. Wunder. 1975. Ecological energetics of small mammals. p. 173-204. In F. B. Golley, K. Petrusewicz, and L. Ryszkowski [eds.] Small mammals: their productivity and population dynamics. Cambridge Univ. Press, New York.

$\rightarrow$ Haberman, C. G., and E. D. Fleharty. 1971. Energy flow in Spermophilus franklinii. J. Mammal. 52:710-716.

$\rightarrow$ Hansen, R. M., and L. D. Reed. 1969. Energy assimilation in Richardson ground squirrels. Am. Midl. Nat. 82:290-293

Jansky, L. 1962. Maximal steady state metabolism and organ thermogenesis in mammals, p. 175-201. In J. P. Hannon and E. G. Viereck [eds.] Proceedings of symposia on arcti biology and medicine. II. Comparative physiology of temperature regulation. Arctic Aeromedical Laboratory, Fort Wainwright, Alaska.

$\rightarrow$ Kaczmarski, F. 1966. Bioenergetics of pregnancy and lactation in the bank vole. Acta Theriol. 11:409-417.

$\rightarrow$ Kaufman, D. W., and G. A. Kaufman. 1975. Caloric density of the old-field mouse during postnatal growth. Acta Theriol. 20:83-95.

Kilgore, D. L., Jr. 1972. Energy dynamics of the yellowbellied marmot (Marmota flaviventris): a hibernator. Ph.D. Thesis, Univ. Kansas, Lawrence. $83 \mathrm{p}$.

Kleiber, M. 1961. The fire of life. John Wiley and Sons, Inc., New York. 454 p.

$\rightarrow$ Kozlovsky, D. G. 1968. A critical evaluation of the trophi level concept. I. Ecological efficiencies. Ecology 49:48-60.

$\rightarrow$ Langenheim, J. H. 1956. Plant succession on a subalpine earthflow in Colorado. Ecology 37:301-317.

$\rightarrow-1962$. Vegetation and environmental patterns in the Crested Butte Area, Gunnison County, Colorado. Ecol. Monogr. 32:249-285.

$\rightarrow \mathrm{McNab}, \mathrm{B} . \mathrm{K}$. 1963. A model of the energy budget of a wild mouse. Ecology 44:521-532.
McNeill, S., and J. H. Lawton. 1970. Annual production and respiration in animal populations. Nature 225:472-474.

dum, E. P. 1960. Organic production and turnover in oldfield succession. Ecology 41:34-49.

Pauley, J. D., H. W. Shirer, and D. D. Pippitt. 1968. A simple pulsed transmitter for telemetering body temperature from free-ranging animals, p. 386-390. In L. Winner [ed.] 1968 IEEE National Telemetering Conference Record, New York.

Petrusewicz, K. 1967. Concepts in studies on the secondary productivity of terrestrial ecosystems, p. 17-49. In K. Petrusewicz [ed.] Secondary productivity of terrestrial ecosystems, Vol. 1. Panstwowe Wydawnictwo Naukowe, Warsaw.

Petrusewicz, K., and L. Hansson. 1975. Biological production in small mammal populations, p. 153-172. In F. B. Golley, K. Petrusewicz, and L. Ryszkowski, [eds.] Small mammals: their productivity and population dynamics. Cambridge Univ. Press, New York.

Petrusewicz, K., and A. Macfadyen. 1970. Productivity of terrestrial animals: principles and methods. IBP Handbook No. 13. F. A. Davis Co., Philadelphia, Pennsylvania. 190 p.

Shirer, H. W., and J. F. Downhower. 1968. Radio tracking of dispersing yellow-bellied marmots. Trans. Kansas Acad. Sci. 71:463-479.

Snyder, R. L., D. E. Davis, and J. J. Christian. 1961. Seasonal changes in the weights of woodchucks. J. Mammal. 42:297-312.

$\rightarrow$ Soholt, L. F. 1973. Consumption of primary production by a population of kangaroo rats (Dipodomys merriami) in the Mohave Desert. Ecol. Monogr. 43:357-376.

Sokal, P. R., and F. J. Rohlf. 1969. Biometry. W. H. Freeman and Company, San Francisco. 776 p.

$\rightarrow$ Svendsen, G. E. 1974. Behavioral and environmental factors in the spatial distribution and population dynamics of a yellow-bellied marmot population. Ecology 55:760-771.

Taylor, C. R., K. Schmidt-Nielsen, and J. L. Raab. 1970. Scaling of energetic cost of running to body size in mammals. Am. J. Physiol. 219:1104-1107.

Travis, S. E., and K. B. Armitage. 1972. Some quantitative aspects of the behavior of marmots. Trans. Kansas Acad. Sci. 75:308-321.

Wiegert, R. G., and F. C. Evans. 1967. Investigations of secondary productivity in grasslands, p. 499-518. In K. Petrusewicz [ed.] Secondary productivity of terrestrial ecosystems, Vol. 2. Panstwowe Wydawnictwo Naukowe, Warsaw. 